\title{
0035. Mitochondrial uncoupling contributes to fever in sepsis
}

\author{
E Greco*, N Arulkumaran, A Dyson, M Singer \\ From ESICM LIVES 2014 \\ Barcelona, Spain. 27 September - 1 October 2014
}

\section{Introduction}

The major sources of body heat production are muscle activity, chemical reactions involving ATP synthesis and usage, coupled (oxidative phosphorylation) and uncoupled (proton leak) mitochondrial respiration. The cause of fever associated with sepsis has not been elucidated, particularly in sedated, ventilated patients who neither perform much voluntary skeletal muscle activity nor shiver.

\section{Objectives}

To determine whether the excess heat production in febrile septic rats is mediated by mitochondrial uncoupling, and related to an increase in global oxygen consumption $\left(\mathrm{VO}_{2}\right)$.

\section{Methods}

Awake, previously cannulated (tunneled carotid and jugular lines), male Wistar rats (approx. 300g body weight) were placed in metabolic cages to measure $\mathrm{VO}_{2}$. Core temperature was measured intermittently with a rectal probe. Twenty-four hours later, sepsis was induced by i.p. injection of faecal slurry. Sham animals received i.p. saline. Intravenous fluid resuscitation $(10 \mathrm{ml} / \mathrm{kg} / \mathrm{h}$ crystalloid $)$ was started $2 \mathrm{~h}$ later. At 6 and 24 hours, animals were randomized to receive an infusion of either the mitochondrial uncoupler dinitrophenol (DNP) (30 mg/Kg) or $\mathrm{n}$-saline over 1 hour. Wilcoxon Rank Sum test was used to compare groups and two-way ANOVA was used to compare change of continuous variables from baseline between groups, with $\mathrm{p}<0.05$ considered significant.

\section{Results}

Sham animals were euthermic at 6 and 24h, and their $\mathrm{VO}_{2}$ was similar to baseline. Infusion of DNP produced similar rises in both temperature and $\mathrm{VO}_{2}(\mathrm{p}<0.05)$ at

Bloomsbury Institute of Intensive Care Medicine, University College London, London, UK

(c) 2014 Greco et al; licensee Springer. This is an Open Access article distributed under the terms of the Creative Commons Attribution License (http://creativecommons.org/licenses/by/2.0), which permits unrestricted use, distribution, and reproduction in any medium, provided the original work is properly cited. both timepoints (Figure 1). By contrast, the septic animals were febrile at $6 \mathrm{~h}$ and $24 \mathrm{~h}(\mathrm{p}<0.05$ vs baseline) and DNP only induced a small, non-significant rise in temperature to the same level as seen in shams (Figure 2). Whereas $6 \mathrm{~h}$ and $24 \mathrm{~h} \mathrm{VO}_{2}$ values were similar to shams, the effect of DNP on $\mathrm{VO}_{2}$ was similar to sham animals at $6 \mathrm{~h}$ but significantly reduced at the $24 \mathrm{~h}$ timepoint (Figure 1).

\section{Conclusions}

In febrile septic animals, mitochondrial uncoupling with DNP only produced a small rise in temperature at $6 \mathrm{~h}$ and $24 \mathrm{~h}$, and a subnormal $\mathrm{VO}_{2}$ response at $24 \mathrm{~h}$. This implies that increased mitochondrial uncoupling was already active in septic rats and this may explain their

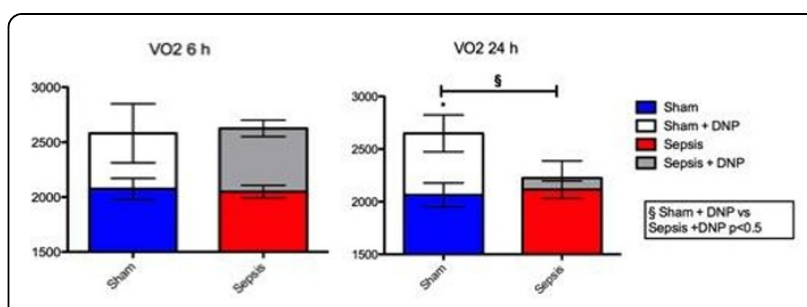

Figure 1

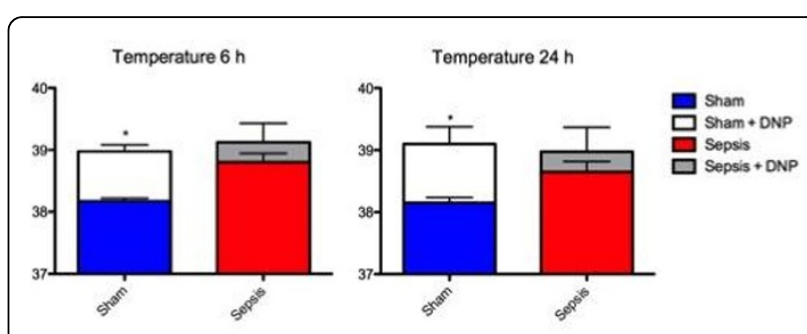

Figure 2 
fever. The proportion of $\mathrm{VO}_{2}$ directed towards ATPcoupled respiration also appears to be reduced.

Published: 26 September 2014

\section{Reference}

1. Rolfe DF, Brown GC: Physiol Rev 1997, 77:731-58.

doi:10.1186/2197-425X-2-S1-08

Cite this article as: Greco et al.: 0035. Mitochondrial uncoupling

contributes to fever in sepsis. Intensive Care Medicine Experimental 2014

2(Suppl 1):08.

\section{Submit your manuscript to a SpringerOpen ${ }^{\circ}$ journal and benefit from:}

- Convenient online submission

- Rigorous peer review

- Immediate publication on acceptance

- Open access: articles freely available online

- High visibility within the field

- Retaining the copyright to your article

Submit your next manuscript at $\gg$ springeropen.com 